Canadian University Music Review

Revue de musique des universités canadiennes

David B. Greene. Mahler, Consciousness and Temporality. New

York: Gordon and Breach Science Publishers, 1984, x, 314 pp.

\title{
Zoltan Roman
}

Numéro 5, 1984

URI : https://id.erudit.org/iderudit/1014017ar

DOI : https://doi.org/10.7202/1014017ar

Aller au sommaire du numéro

Éditeur(s)

Canadian University Music Society / Société de musique des universités

canadiennes

ISSN

0710-0353 (imprimé)

2291-2436 (numérique)

Découvrir la revue

Citer ce compte rendu

Roman, Z. (1984). Compte rendu de [David B. Greene. Mahler, Consciousness and Temporality. New York: Gordon and Breach Science Publishers, 1984, x, 314 pp.] Canadian University Music Review / Revue de musique des universités canadiennes, (5), 337-342. https://doi.org/10.7202/1014017ar

All Rights Reserved (C) Canadian University Music Society / Société de musique des universités canadiennes, 1984
Ce document est protégé par la loi sur le droit d'auteur. L’utilisation des services d'Érudit (y compris la reproduction) est assujettie à sa politique d'utilisation que vous pouvez consulter en ligne.

https://apropos.erudit.org/fr/usagers/politique-dutilisation/ 
David B. GREene. Mahler, Consciousness and Temporality. New York: Gordon and Breach Science Publishers, 1984, x, 314 pp.

In company with only a few other composers, Mahler speaks to us directly about joy and finitude, courage and ordinariness, love and emptiness. He confronts us with matters that are too momentous to grasp at once and too important to be allowed to slip away. If we are to tighten our grip on them, we would do well to begin by describing the vehicles by which they come to us: Mahler's musical processes.... To this end I have analyzed in detail four of Mahler's symphonies ....

Music analysis does not have a vocabulary for ultimate matters. For help in pointing toward the vision that the music carries, I have turned to the phenomenologists of our century-particularly Husserl, Heidegger and Sartre-who have concerned themselves with many of the same matters as Mahler. They have systematically thought about the nature of human existence, and, in that context, about the experiences of finitude and joy. The particular meaning they give to consciousness and temporality encapsulates their thinking.... (p. ix).

Thus the prefatory statement of the premises and procedures of this book. The Preface is followed by an Introduction, and four chapters dealing with, in order, the Fifth, Third, Eighth, and Ninth Symphonies (several other works by Mahler are discussed in interpolated excursions of varying length). The book concludes with a detailed Subject and Name Index; it is richly illustrated with musical examples and diverse figures and tables. The text is not as free of typographical errors as one might have hoped for from "science publishers"; the worst one of these (the omission of a passage of unknown length on page 13) renders a key section of the Introduction unintelligible. Misprints and other production errors, though, turn out to be the least of this work's flaws.

For those of us who had welcomed David Greene's initial venture into the application of the principles of phenomenology to musical analysis and interpretation (see Greene 1982) as a tentative but promising-even exciting- "first" in a new field, the book before us cannot but be a considerable, and in some respects downright vexatious, disappointment. For in the earlier work, even though its 200-odd pages incorporated a survey of the relevant philosophical thought from Kant to McLuhan, and from Langer to Beardsley, musical concerns and aims were seldom lost from sight, and were invariably paramount in the positing of conclusions, however tentative or, in some cases, surprising. After all, the author himself stated in the Preface to that work that "insights into temporality offered in musical works cannot be exhaustively translated into verbal terms" (p. viii) (my italics). However, that is precisely what Greene now appears to have attempted to do in Mahler, Consciousness and Temporality. Regrettably, all balance 
between philosophy and music is thus absent from this book, and phenomenology is allowed to run amok. In the end-to the great disservice of the author and the reader, but most of all of Mahler-the music serves only the purpose of supporting the author's philosophical tenets. (As I will show later, this process not infrequently degenerates into making the music fit the idea, if it does not do so readily through analytical observation.)

I could not just yet say whether I will ever become an unreserved champion of the phenomenological exegesis of music. This is due as much to an admittedly less than complete grounding in philosophical thought and process, as to the seemingly unshakable sense of discomfort I have with that original and most basic principle of the method, namely, Husserl's insistence on phenomenology as an a priori investigation rather than as an empirical technique. At the same time, I am by no means an advocate of cut-and-dried (dare I say, sterile) musical analysis. On the contrary, I have always found the best of the hermeneutical studies of Mahler's music, from Bekker (see Bekker 1921) to Floros (see Floros 1977), a source of pleasure and enlightenment. I well recall a number of heated discussions with the late Erwin Ratz-that eminent and impassioned apostle of Formenlehre-on the respective merits of "analysis" and "interpretation," while in my own approaches to Mahler's music, I have more than once called upon the assistance of other disciplines, including philosophy (e.g., see Roman 1973 \& 1980). It is my firm belief, nevertheless, that any analytical or interpretive system, method, or technique (or any combination of them) is useful and legitimate only to the extent to which it serves the purpose of contributing to an understanding and appreciation of the music, of illuminating it, of making it more intelligible to the interested and the receptive. And it is on this account, above all, that Greene's Mahler falls down: in this book, the music is made to serve the ends of the method.

And now I must illustrate my objections to what is clearly so much of this book. It is as well to start with the citing of some specific examples which relate to the need, mentioned above, for any musical analysis or interpretation to make its subject "more intelligible." In the process of summing up his examination of the Scherzo of the Fifth Symphony, Greene writes:

Such is Scherzo's picture of life. It is a process that consists of opposites that turn out to be only apparent, yet also real. It is a process whose resolution consists of happening to recognize-being forced to and yet also choosing to and yet really neither being forced nor choosing to recognize-that opposites are only apparent, but because one is always in and never above the process there is no final recognition of the illusory character of the opposites; and because the recognition must happen again and again, each time as though it had never happened before, the opposition is also real and not merely apparent (p. 103). 
In relation to another "Scherzo" (in actual fact, the second section of Part Two of the Eighth Symphony), and having introduced various elements of Sartre's concept of the temporality of ordinary consciousness (unquestionably the most indigestible portion of the entire book), Greene has this to say:

The temporal process of Mahler's Scherzo offers a somewhat different contrast to the temporality of Sartre's for-itself entity. This contrast can be best seen by reviewing Sartre's analysis of the present. The present would seem to be definable as a plenitude of being, for "what is present is-in contrast to the future which is not yet and to the past which is no longer." Yet the more vigorously one purges the present of what it is not (the past and the future) the more it becomes the nothing of an "infinitesimal instant." The meaning of the present, however, is not this nothing, but the presence of the foritself to being-in-itself. Only a for-itself entity can be present to another entity, for a being that is present to something "cannot be at rest 'in-itself'" (p. 245).

(Lest I should be accused of intentionally swaying the reader's opinion, let me assure him or her that such passages are virtually without number in this book, and that their meaning is only minimally impaired or altered by being removed from context.)

If the ability of passages such as the foregoing to contribute to an understanding of the music is, at the very least, dubious, what then of the philosophically less encumbered (i.e., more conventionally analytical and/or interpretive) sections of the book? At least at first glance, this area appears to hold more promise of genuine instruction and illumination. Greene had already shown in his Beethoven book that he is an able and versatile analyst. However, something that was a fairly minor problem there-namely, a certain fondness for "textbook" categories, norms, and terminology - turns into a significant weakness in a book which deals with music that-more often than not, and better than any other of its time-exemplifies the abandoning of inherited practices, if not the very process of dissolution. Time and again, Greene describes various elements of form as "conventional," "standard," or "somewhat unusual" (p. 145); compares them to "ideally coherent processes" (p. 24); or signals a priori assumptions with respect to Mahler's "defects," "incongruities," and the like (pp. 38f.). (At the same time, it is interesting to note that the author actually disclaims the efficacy of conventional analytical terminology and procedure-see pp. ix, 39, 131, passim.)

The problematic nature of many of the analytical sections is further increased by the frequently eclectic mix of techniques employed. The combination of the aforementioned conservative concepts with Schenkerian terminology-especially when it is clearly so intended in some places (e.g., Fig. 102), while used to mean something 
else in others (e.g., pp. 269ff.)-and with such lesser-known techniques as the Cooper-Meyer analysis of rhythm, easily leads to confusion. Especially when the whole is framed by, and liberally mixed with, phenomenological discourse and speculation.

As I implied earlier, the worst sins of this work are represented by the instances-unfortunately, rather numerous-in which questionable interpretation and faulty analysis combine in the service of upholding extra-musical preconceptions and assumptions (whether borrowed or fashioned for present purposes). As almost the entire chapter devoted to the Ninth Symphony is characterized by this fault, a general, as well as some more specific examples selected from it will illustrate my point.

One of the hoariest and, at the same time, potentially most misleading axioms in the Mahler-canon derives from his perceived position as a fin-de-siècle composer. As such, it has been considered well-nigh obligatory to interpret his entire œuvre as one that sounds, in various ways, the final "farewell" of an age, of a society, of the Empire, of a musical style-and so on, and so forth, literally ad nauseam. Furthermore, since his bad heart had been diagnosed by the time he wrote them, it follows-so the reasoning goes-that Das Lied von der Erde and the Ninth Symphony are the two works in which Mahler's "resignation," "treatment of finality" (if not out-and-out death-wish, personal and universal) reach their peak (or, perhaps I should say, depth). As it is clearly outside the limits of this review to trace in detail the historical and other reasons for this misinterpretation, and to marshal all the evidence against it, I have to content myself with quoting some passages from two of Mahler's letters. These will at least give an indication of his own view of the Ninth, and of his frame of mind a scant few months before his death (both letters are in Martner 1979).

The first letter was written to Bruno Walter in the summer (probably August) of 1909, and includes the following passages:

$\ldots$ I have been working very hard and am just putting the finishing
touches to a new symphony ... The work itself.... is a very satis
factory addition to my little family. In it something is said that I
have had on the tip of my tongue for some time-perhaps (as a whole)
to be ranked beside the Fourth, if anything.... (p. 341).

The second letter dates from the late autumn (probably November) of 1910, and was written to Karl Moll. The relevant passages, quoted below, refer to a plot of land acquired by the Mahlers shortly before, and to their plans for the house to be built on it:

We received your precious news today. We had both been eagerly awaiting the outcome, and there is a fair and true aim for all our hopes and desires....

I should like now, before you finish the plans for the house, to 
urge you to be sure to include a bathroom with a W.C. each (no matter how small) for Almschi and for me for I can hardly find any "residence" comfortable-or, indeed, hygienic-without such a convenience.... (p. 368).

Now, it seems to me reasonable to ask: does the first letter really refer to a dirge-to-end-all-dirges (especially with the comparison to the Fourth!)? I think not. As to the second letter, was it really written by someone tired of and finished with life, and merely biding his time until merciful death claimed him? Again, I do not think so. Yet, Greene's phenomenological exegesis of the Ninth Symphony is based entirely on his unquestioning acceptance of this inherited interpretation. What is worse, his musical analysis (from terminology to conclusions) is governed by such considerations, rather than by objective observations.

Greene's analysis of the Ninth Symphony (especially of the first movement, but ultimately of the entire work) hinges on the musical and extra-musical significance he attributes to a so-called "Lebewohl" motif (F-sharp-E-D) and its "transformations." Considered most important among these is what the author calls the "ewig" motif (F-sharp-E), with reference to "Der Abschied", the closing song of Das Lied von der Erde. According to Greene, "at the end of the Ninth's opening movement, as at the end of 'Der Abschied,' the 'ewig' motif leaves the listener suspended indefinitely without a goal" (p. 267). Even if we accept the rather artificial view of motivic "transformation" as between two consecutive major seconds and a single major second (incidentally, one imagines at least Hugo Wolf objecting strenuously to a categorical description of the "Lebewohl" motif as "two descending whole steps"-p. 263), the above comparison of the two endings is wholly erroneous. In point of fact, the first movement of the Ninth ends on a clear D (the tonic); that it is "played two octaves higher" (intended as a disclaimer by Greene), and is unaccompanied, simply makes it that much stronger as an ending. "Der Abschied," on the other hand, effectively ends on a tonic chord of the added sixth, the so-called "ewig" motif having already ceased.

In a different vein, Greene's designation (and subsequent analysis) of the opening six measures of the first movement of the Ninth as an "introduction" indicates a fundamental misunderstanding of the most significant (and future-directed!) musical traits of Mahler's late works. It is also in this connection that the terms "melody," "accompaniment," "foreground," and "background" are most misused. The fact of the matter is that these measures are no more (in fact, far less) an "introduction" than is the opening of Beethoven's Ninth, or those of practically any Bruckner symphony. The completely linear and highly pointillistic microcosm of these six measures is a germinal pod for the entire movement (and much of the symphony) to follow; not a single pitch or rhythm is in a subsidiary relationship to any other. 
Can I, then, recommend this book to anyone? Certainly not to those who may be drawn to it by the first word of the title (emblazoned on the cover in large red letters). A novice Mahlerite may be put off his quest for the rest of his life; the experienced one may find nothing but frustration and endless opportunities for disagreement. That leaves the confirmed phenomenologist-and on his behalf I would not presume to speak.

Still, I hope for better things from Greene (assuming that he pursues his apparently strong interest in the wedding of phenomenological exegesis and musical analysis). He had already shown us the possibilities inherent in this method of investigation in his Beethoven study; it now remains to find a musically effective and workable compromise between the tentative promise of that book, and the unhappily turgid overkill represented by this work.

Zoltan Roman

\section{REFERENCES}

BEKKER, P.

1921: Gustav Mahlers Sinfonien. Berlin: Schuster \& Löffler.

FLOROS, C.

1977: Gustav Mahler (2 vols.). Wiesbaden: Breitkopf \& Härtel.

GREENE, D.B.

1982: Temporal Processes in Beethoven's Music. New York: Gordon and Breach Science Publishers.

MARTNER, K., ed.

1979: Selected Letters of Gustav Mahler. New York: Farrar, Straus, Giroux. ROMAN, Z.

1973: "Connotative Irony in Mahler's Todtenmarsch in 'Callots Manier'," The Musical Quarterly, LIX/2, 207-22.

1980: "The Limits of Romantic Eschatology in Music and Literature: from Byron and Berlioz to Mahler and Kafka," Studia Musicologica Academiae Scientiarum Hungaricae, 22, 273-98. 